\title{
Calcified pure uterine lipoma mimicking myoma
}

\author{
Leiomyomu taklit eden kalsifiye uterus lipomu
}

\author{
Arghya Bandopadhyay ${ }^{1}$, Sailes Ray ${ }^{1}$, Pranati Bera ${ }^{1}$, Mimi Gangopadhyay ${ }^{1}$, Indranil Chakrabarti ${ }^{1}$, Biswajit Dey ${ }^{2}$ \\ ${ }^{\prime}$ North Bengal Medical College \& Hospital, Sushrutanagar, Darjeeling, India \\ ${ }^{2}$ Medica North Bengal Clinic, Siliguri, Darjeeling, India
}

\section{Abstract}

Pure lipoma of the uterus is a rare entity and only a few cases have been reported in the literature. Clinical symptoms and signs are similar to those found in leiomyoma and create preoperative diagnostic confusion. The histogenesis is still unclear. We report the case of a 70 year-old woman with pure lipoma of the uterus with calcification. (J Turkish-German Gynecol Assoc 2010; 11: 113-4)

Key words: Lipoma, uterus, calcification

Received: 11 October, 2009

Accepted: 3 November, 2009

\section{Özet}

Uterusun saf lipomu seyrek görülen bir hadisedir ve literaturde sadece birkaç vaka bildirilmiştir. Klinik semptomları ve yakınmaları leiomyomdaki gibi olduğundan preoperatif tanıda konfüzyon yaratır. Hala histogenezisi netleştirilememiştir. Biz burda 70 yaşında saf lipoması olan ve uterusu kalsifiye olmuş bir vakayı bildirdik.

(J Turkish-German Gynecol Assoc 2010; 11: 113-4)

Anahtar kelimeler: Lipoma, uterus, kalsifikasyon

Geliş Tarihi: 11 Ekim 2009

Kabul Tarihi: 03 Kasım 2009

was uneventful. Grossly, the uterus and cervix together measured $13 \times 8.5 \times 9 \mathrm{~cm}$. in size. The cut section showed a well circumscribed yellowish intramural mass with punctate white areas measuring $6.5 \times 6.5 \mathrm{~cm}$ (Fig. 2). Multiple sections were taken and stained with hematoxylin and eosin. The sections showed lobules of mature adipocytes separated by thin vascular connective tissue. The myometrium was pushed to the periphery forming a pseudocapsule along with fibrous tissue (Fig. 3). There was linear calcification at the periphery, and blotchy calcification within the fatty tissue. The endometrium was atrophic. Von-Kossa stain proved the white blotchy areas to be calcification.

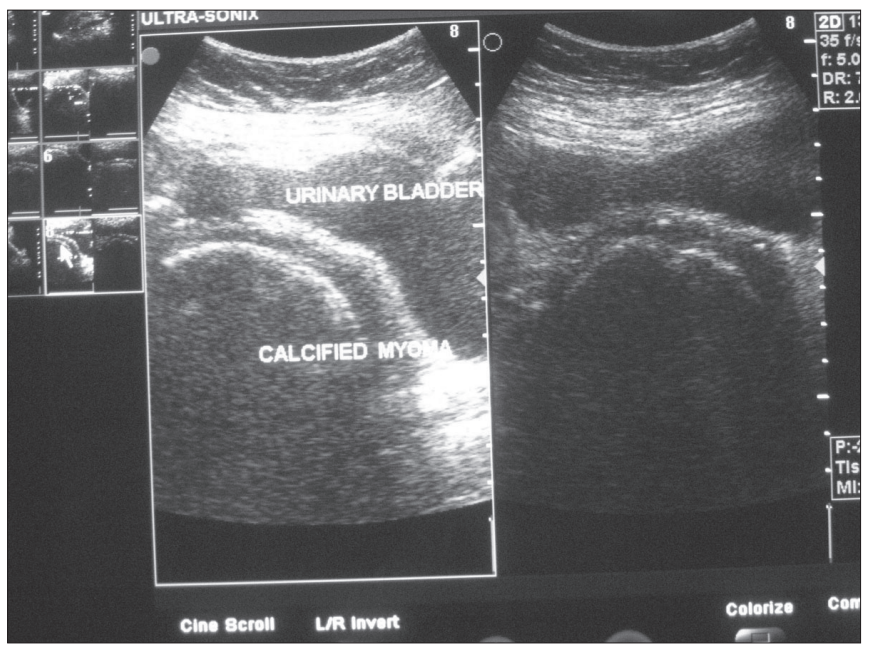

Figure 1. USG diagnosing the mass as calcified myoma 


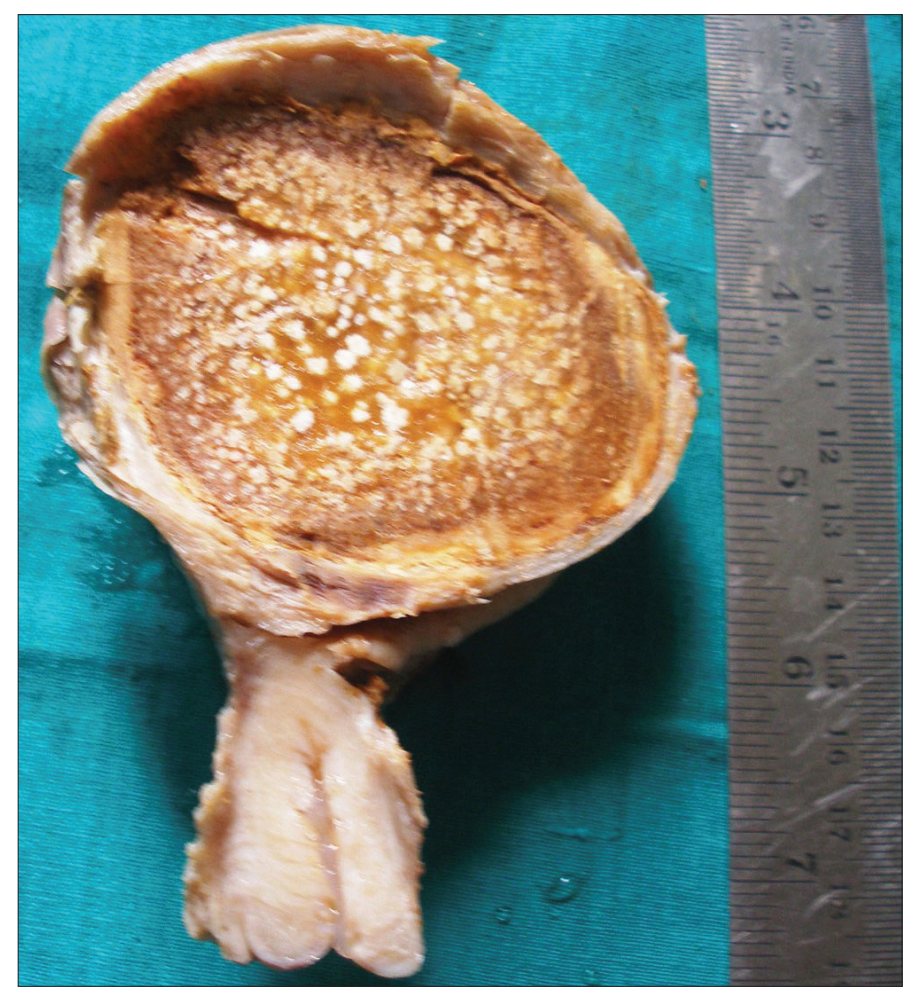

Figure 2. Gross appearance showing circumscribed yellowish uterine mass with punctate white areas

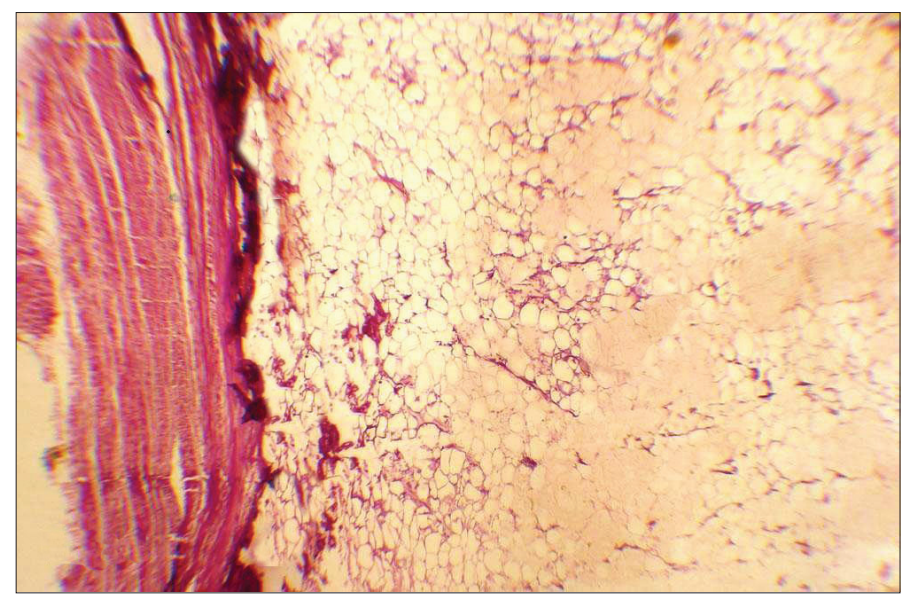

Figure 3. Section showing compressed myometrium along with adipose tissue, $H \& E, \times 40$

\section{Discussion}

Fatty uterine tumors may be defined as tumors composed entirely or in part of adult type adipose tissue. Smooth muscle and fibrous tissue are usually intermixed (5). These fatty tumors include pure lipoma and mixed lipoma such as myolipoma, lipofibroma, lipomyoma, and fibromyolipoma (6). Some of the pure lipomas are co-incidentally associated with other lesions. Dey and Dhar in 1993 reported a case of uterine lipoma in association with struma ovarii (7), DiGesu'G et al. in 1998 found pure uterine lipoma with endometrial carcinoma (8), Dilek TU reported a case of pure uterine lipoma with cervical carcinoma (9).
Strikingly, very few cases of isolated pure lipoma of the uterus with calcification were reported. The incidence of uterine fatty tumors varies from 0.03 to $0.2 \%$ (10).

Ninety percent of fatty tumors of the uterus occur in patients over the age of 40 years (5) and their clinical presentation is similar to uterine leiomyomas and diagnosed rarely by USG or X ray. The age of our patient was 70 years and the mass was misdiagnosed as a case of calcified myoma. For preoperative diagnosis MRI is the best modality of radiological investigation (4).

The uterine fundus is the typical site for uterine fatty tumors. This is comparable with our case. The tumor may be located at the cervix and less commonly in the subserosal location (5).

There are no accepted criteria for distinction of a pure lipoma from a mixed lipoma/leiomyoma. According to D.J. Pounder (5) the diagnosis of pure lipoma of the uterus should only be made when any smooth muscle cells present, are confined to the periphery of the tumor. Histopathology showed purely adipose tissue interspersed with fibrous septa in our case. One of the unique features in our case was the presence of dystrophic calcification. Only a few cases of pure lipoma with calcification are reported. Theories on histogenesis lay emphasis on explaining the presence of adipose tissue, an element not usually found in the uterine corpus. According to Bride et al. (6) fatty degeneration of connective tissue of the myometrium may be responsible for differentiation into fatty tissues. A morphologic and histogenic analogy has been drawn between uterine fatty tumors and renal angiolopomas (2). It has been suggested that uterine fatty tumors are hamartomas or most recently choriostomas. It is also believed these tumors, or even the rarer pure uterine lipiomas, result from adipose tissue metaplasia in leiomyoma (5).

\section{Conflict of interest}

None declared

\section{References}

1. Harish K, Sharmila SP, Revadi PS, Prabha CV, Padmini J, Murley PR. Isolated pure lipoma of uterus- a case report. Indian J Pathol Microbiol 2005; 48: 377-8.

2. Demopulous RI, Denavdez F, Kaji V. Benign mixed mesodermal tumors of the uterus: a histogenetic study. Am J Clin Pathol 1973; 60: 377-83.

3. Brandfass RT, Everts-Suarez EA. Lipomatous tumors of the uterus. A review of world's literature with report of a case of true lipoma. Am J Obstet Gynecol 1955; 70: 359-67.

4. FujimotoY, Kasai K, Furuya M, Honda N, Tojo R, Satio S, et al. Pure uterine lipoma. J Obstet Gynaecol Res. 2006; 32: 520-3.

5. Pounder DJ. Fatty tumors of the uterus. J Clin Pathol 1982; 35: 1380-3.

6. Gupta DP, Sharma ML. Lipoma of uterus:a case report. Indian J Pathol Bacteiol 1966; 9: 80-3.

7. Dey P, Dhar KK. Lipomatous tumors of uterus. J Indian Med Assoc 1993; 91: 99.

8. Di Gesu'G, Cormio G, Di Vagno G, Melilli GA, Renzlli G, Selvaggi L. Pure lipoma of the uterus in association with endometrial carcinoma. Eur J Obstet Gynecol Reprod Biol 1998; 80: 199-200.

9. Dilek TU, Akcin U, Erdem O, Tiras B, Dursun A. Uterine lipoma and coincidental cervical cancer: a case report. Int J Gynecol Cancer. 2006; 16: 445-7.

10. Senta Z, Siddiqui MS, Hussainy AS, Muzaffar S, Hassan SH. Pure lipoma of the uterus: an extremely rare entity. Indian J Pathol Microbiol 1999; 42: 383-4. 